\title{
Glemte sykdommer
}

Det kan være nyttig å se tilbake på «glemte sykdommer». I Tidsskriftet nr. 15/1918 (Tidsskr Nor Lægeforen 1918; 38: 663-78) sto under spalten Hygieniske meddelelser og social medicin en artikkel om difteri. Sykdommen herjet sporadisk og opptrådte i bølger.

Medd. nr. 2 fra Buskerud amts bakteriologiske laboratorium.

\section{Om difteri.}

Foredrag i Drammen lægeforening 9de april 1918.

Av W. Grimsgaard, distriktslæge.

(...)

Difterien viser i sit epidemiologiske forløp en eiendommelig tilsynelatende sprang vis optræden, saavel med hensyn til morbiditet som mortalitet. I Europa viser den sig antagelig først som nogen erkjendbar større epidemi i 1500 og 1700 for i slutningen av dette aarhundrede helt at forsvinde. I det 19de aarhundrede er vi oppe i flere store epidemier, og det er først fra dette aarhundredes begyndelse, at sygdommens patologiske natur erkjendes og nærmere blir bestemt (Bretonneau). Vi har den første større epidemi i 1820-1830-aarene, og saa faar den i 1840 -aarene igjen en større utbredelse; i N o r g e viser denne sig at herje en 6 aars tid fra ca. 1840 til 1856 (Kielland). Den største pandemi optrær i slutningen av 1850-aarene og varer her i Norge fra 1859 til 1867 med klimaks i 1861, hvor antal angrepne naar over 10000 ; i 1878 har epidemien naadd det minste antal angrepne - litt over 800 (fig. 1). Den tredje større epidemi i Norge tar sin begyndelse i 1882 og naar sin største utbredelse i 1890 , hvor vi igjen er oppe i over 10000 tilfælder; dennes herjing varer ca. 13 aar indtil 1895 for saa at naa sit laveste tal i 1900, da ca. 1700 er angrepet. - Vi er allerede et par aar efter (1902) paa den fjerde bølges steilt opadstigende kurvelinje, som naar sin top i 1906 og 1907 med vel 6800 tilfælder; nu falder vistnok kurven, men yderst langsomt; i 1914 er saaledes antalet vel 4400; fra kurven for Kristian ia at dømme skulde vi allerede i 1916 muligens staa likeoverfor en ny stigning.

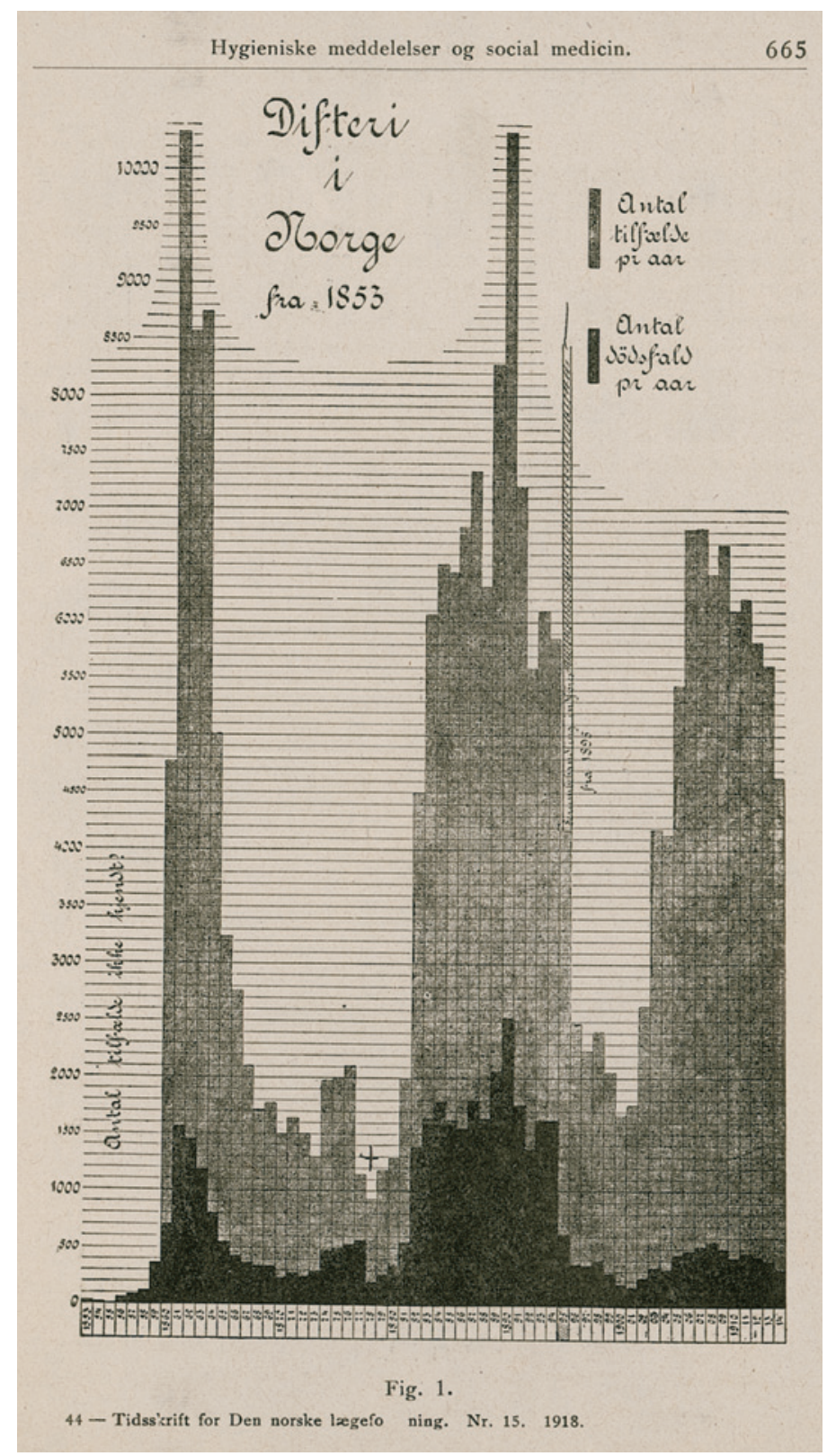

